\title{
Why is Gender Inequality Still Appearing in Garment Factories, in Indonesia?
}

\author{
Annisa Halimah Imron ${ }^{1}$, Muthia Pramesti ${ }^{1 *}$, Sari Wahyuni ${ }^{1}$ \\ ${ }^{1}$ Department of Management, Faculty of Economics and Business, Universitas Indonesia \\ Email: muthia.pramesti@gmail.com
}

\begin{abstract}
In Indonesia, since the majority of the workers in garment factory are females, they have a significant role on the succession of the factory. The gap between genders might create problems for female workers, which will lead to gender inequality at the workplace. This study aims to study the working conditions for the garment factories workers in Indonesia based on gender and to find out the causes of gender inequality in the factories during the period of 2012-2014. This is due to the empirical evidences which suggest that gender equality in the workplace is beneficial for the firm's performance, if managed properly. This study employed both quantitative and qualitative methods. The quantitative method was used to descriptively explain the data of the workers based on survey collected by Better Work. The qualitative method was utilized to review the literatures on barriers in the workplace for women both in Indonesia. It was discovered that there are some elements that influence the persistence of gender inequality in Indonesia.
\end{abstract}

Keywords: Garment factories, gender equality, female workers, working condition

\section{Introduction}

Indonesia is leading with employment in garment industry that reached up to 3.8 million (ILO, 2015). The development resulted the country to have a fruitful $18.4 \%$ garment export growth in a decade from 1995 to 2014 (ILO, 2015). To stay in the competition, one of the methods that could be applied is to choose cost-saving strategy. Unfortunately, it is still mainly compensating the humane aspect of the labor and this is especially true for developing countries. An example is when Nike was revealed to be supplied by an Indonesian factory that treated their workers in severe abuse which include being kicked and being forced to stay under the sun after not reaching the target production (Braddock, 2011).

Due to the potential of inhumane treatments for the workers in Indonesian company, this research focused on the work condition garment factories located in Indonesia. It is to be noted that a signature trait of garment industry that is not shared with most industries is the fact that the jobs are mainly dominated by female workers. The share of women workers in the garment industry varied from the proportion of three-fifths in Indonesia to around four-fifths in Cambodia (ILO, 2015). 
From the aspect of the workers, the garment industry is able to bring positive impact to the female workers. This is due to the self-esteem that the women received from working (ILO, 2014). A report in Bangladesh shown how the garment industry has unexpectedly created some sort of revolution among women. The women in Bangladesh now have the option to leave their village by working for garment factories in the city and earn their own salaries, thus have more freedom in deciding matters such as education and marriage (Ghosh, 2014). In East Asia, growth in the textile manufacturing industries has increased women's wage work and improved female and child health and education outcomes (World Bank, 2013).

However, previous findings have suggested that the vast feminization of the labor force in export-oriented production, such as garment, is due to the exploitative dimensions that come in employing women which include low wages, absence of security benefits, a lack of promotion prospects, and vulnerability to sexual harassment (Better Work, 2013). Overall, female workers continue to be preferred due to the perception that they are more docile and pliable in doing their jobs (Better Work, 2013).

The Better Work program provides datasets that describe workers' objective characteristics along with their subjective perceptions on working conditions and their own well-beings hence give a chance to better understand the circumstance of women workers in the exportoriented apparel sector. The assessments done by Better Work follows the core international labor standards and the national labor law for each country. Hence, using the datasets provided by Better Work, the author is investigating the working conditions of the garment factories worker based on gender. The analysis is focused into interrelated five dimensions: occupational segregation, pay and hours of work, training and promotion, health and well-being, perceived barriers and voice. And if significant disparities appear, the author is looking to understand the reasons behind the situation.

\section{Gender Equality Toward Performance}

The topic of diversity management gathers a lot of attention in the recent years. Businesses are recognizing that non-financial performance is interlinked to financial performance and in turn, understand that managing social impacts present risks, but more importantly, presents opportunities as well. Many organizations today put focus on facilitating diversity and equality under the assumption that diversity and equality management can lead to the improvement of firm performance. The practices of gender diversity in the workplace can be derived from resource-based theory. This theory views an organization can obtain a sustained competitive advantage if it takes an advantage of its valuable, rare, inimitable, and non-substitutable resources.

A tangible competitive advantage of the diversity practice is for firms to be able to save on employee turnover costs. The impressions of pro-diversity workplace are significantly and negatively related to turnover intentions, as well as related to favorable worker attitudes. One Europe Commission study suggested that 58 percent of firms with diversity programs show higher productivity resulted from increased employee motivation and efficiency. Gender diversity can possibly be a source of the intangible and socially complex resources of market insight, creativity and innovation, and improved problem-solving. 
It is important to note that firms cannot simply impose diversity in the workplace and hope to obtain the benefits of it without having the appropriate management. Firms that induce a diverse workplace but failing to manage that diversity adequately may even experience negative outcomes - such as a lack of consensus and dysfunctional conflict. Therefore, Armstrong, et al. (2010), suggested that the triggers for negative outcomes can be avoided if diversity and equality is managed effectively to obtain the desired business benefits of it. The effective management include maintaining top management support, integrating diversity and equality in the organization's mission and vision-also in establishing objectives and reward and recognition, providing diversity and equality-related trainings across all levels in the firm, and assessing the impact of diversity and equality within the firms.

\section{Methodology}

This study is using both quantitative and qualitative research. The quantitative research is done with descriptive research using cross-sectional design which involve collecting data from a population at one specific point in time. The qualitative research is done after the descriptive research conducted and the author found interest in understanding the causes for gender inequality Indonesia for the context of garment factories. The type of qualitative research used is exploratory research on secondary data.

The sampling method for this study is judgement sampling. This method of sampling is a part of purposive sampling where the sampling uses few criteria decided by the researcher in accordance to the purpose of study. Table 1 shows the number of participants from each country during the period ofobservation.

The data for this study is using secondary data. The quantitative data is provided by Better Work in a form of raw dataset and the qualitative data use published materials such as journals and reports. The method of data collection of Better Work is by conducting survey involving both managers and workers. In each factory, 30 randomly selected workers and four managers undertake a 'self-interview' using a computer program running on a PC tablet.

This study employed the independent t-test to analyze the data. The method was chosen because there are two unrelated groups being analyzed, which are female workers and male workers, and this statistical test can determine whether there is a statistically significant between the means in two unrelated group, with the significance level of 5 percent. If the research conducts two tests on the same subject to analyze the effects of treatment pretest and posttest, then the method of paired t-test is more proper. The data analysis is using the statistic software, Stata 13. The data analysis method of the qualitative research for this study is using literature review. The data analysis is using the software for qualitative data analysis, NVivo 11.

\section{Results and Discussion}

\section{Dimensions of Working Condition Based on Gender}

In the figures of the following section, disparities in findings between male and female workers 
Table 1. The number of participants in Indonesia

\begin{tabular}{cc}
\hline Year & Indonesia \\
\hline 2012 & 971 \\
\hline 2013 & 581 \\
\hline 2014 & 404 \\
\hline
\end{tabular}
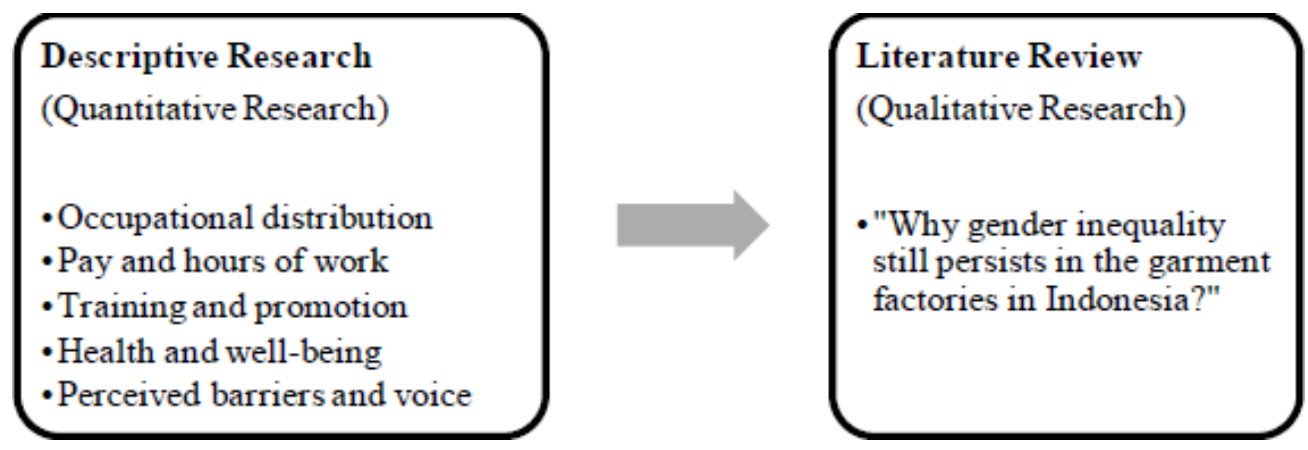

Figure 1. The research flow

are highlighted according to their significance. The chosen significance level is at 5 percent hence the p-value cannot be higher than 0.05 - the set bar in the figure - to be deemed as significant.

\section{Occupational Distribution}

In Indonesia, the occupational segregation based on gender seems to be quite prominent with almost all the occupations - except for spreader and checker - to have significant employment disparities between female and male workers in at least one year. The occupation of sewer has been defined as "females job" due to the stereotype that women are more skilled in household related-work and believed to have greater finger dexterity compared to men. This is in line with the findings in year 2012 and 2014 in Figure 2.

Meanwhile, occupations such as mechanic, supervisor, cutter, and packer are significantly dominated by male workers in at least one year during period of observation. According to Anker, women are commonly deemed to be unsuitable for such works due to the stereotypes that women have lesser ability to obtain more complex skills and lesser physical strengths.

\section{Pay and Hours of Work}

In the Indonesian data, the indicator for piece rate is not available and hence has been omitted. During the first year of observation, the difference of wage between female and male workers is highly significant with $p$-value of 0.0006 . A steady increase in the wage of female workers occurs during the period of observation and the disparities of wage are no longer significant 


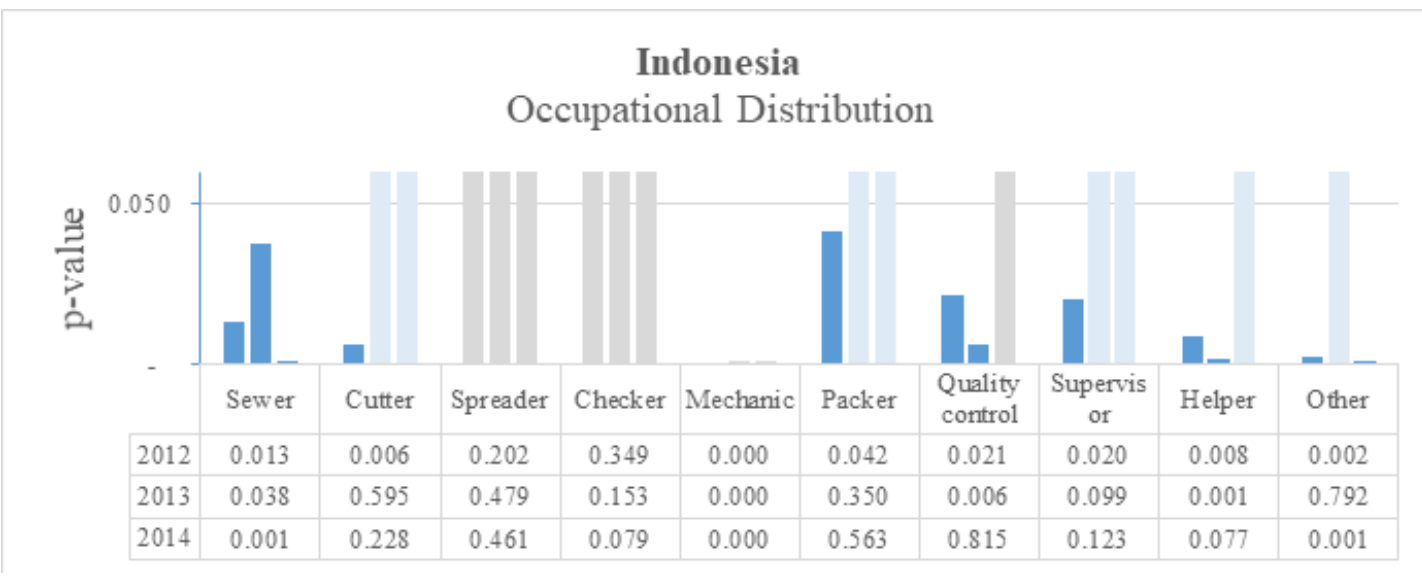

Figure 2. Indonesia: Occupational distribution by gender

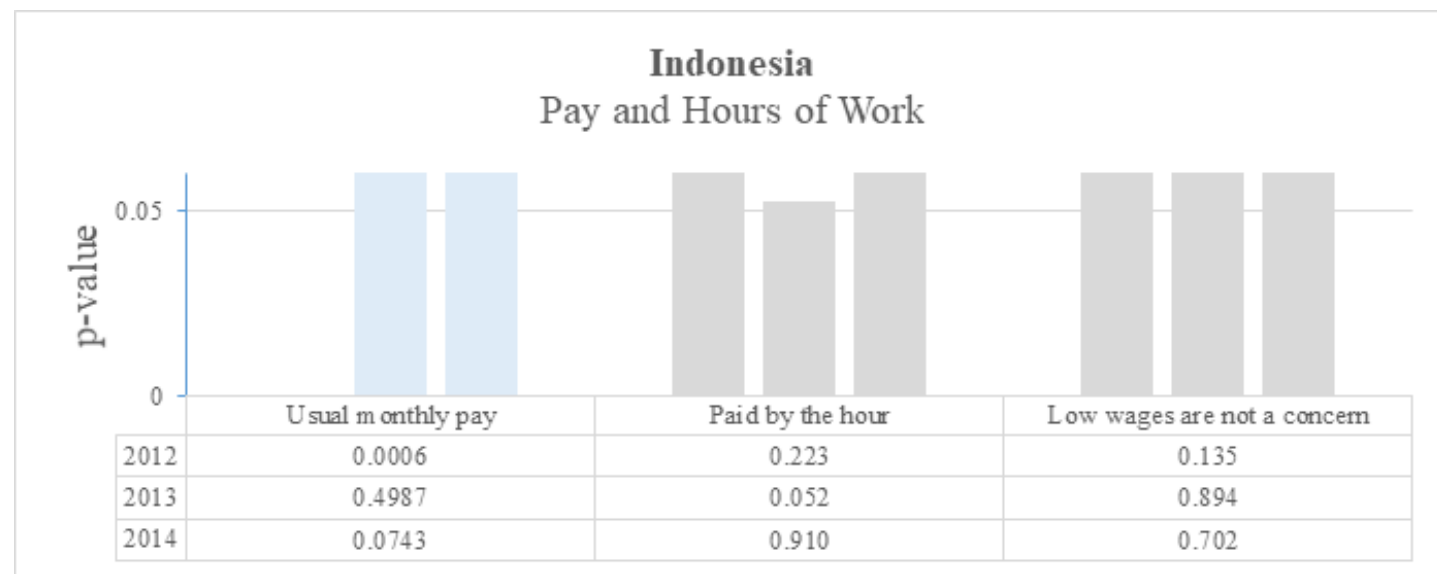

Figure 3. Indonesia: Pay and hours of work

in the last two years. The female workers have higher wage due to a decrease of wage among male workers in 2013.

\section{Training and Promotion}

From Figure 4, the average highest education attained for garment workers in Indonesia is junior high school level and this is in line with the education program launched by Indonesian government in 1984-where children of age 7-15 years old are obligated to study for at least nine years or the amount required to finish junior $\mathrm{h}$ igh $\mathrm{s}$ chool. However, $\mathrm{t}$ he $\mathrm{m}$ ale workers significantly have higher education relative to the female workers. Promotions are also apparent to be received by more male workers during the period of observation and become significant in the year 2012 and 2014. Further indicating that the factories may still favor the male workers more than the female workers. No significant differences a re $n$ oted $r$ egarding $t$ he trainings received.

In Figure 5, a cohesive significant difference exists regarding the Indonesian workers that had sought for treatment and more female workers seem to be profound in handling health and 


\section{Indonesia}

Training and Promotion

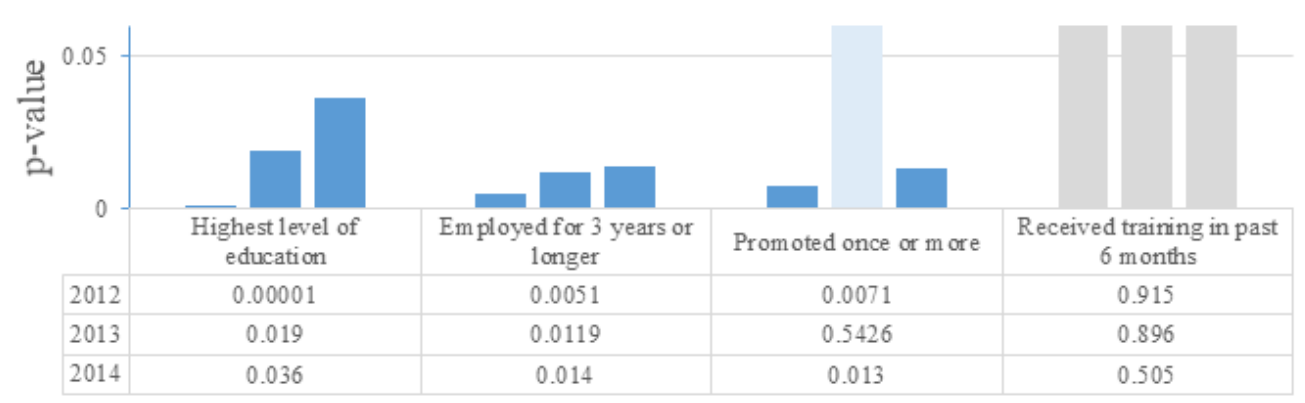

Figure 4. Indonesia: Training and promotion

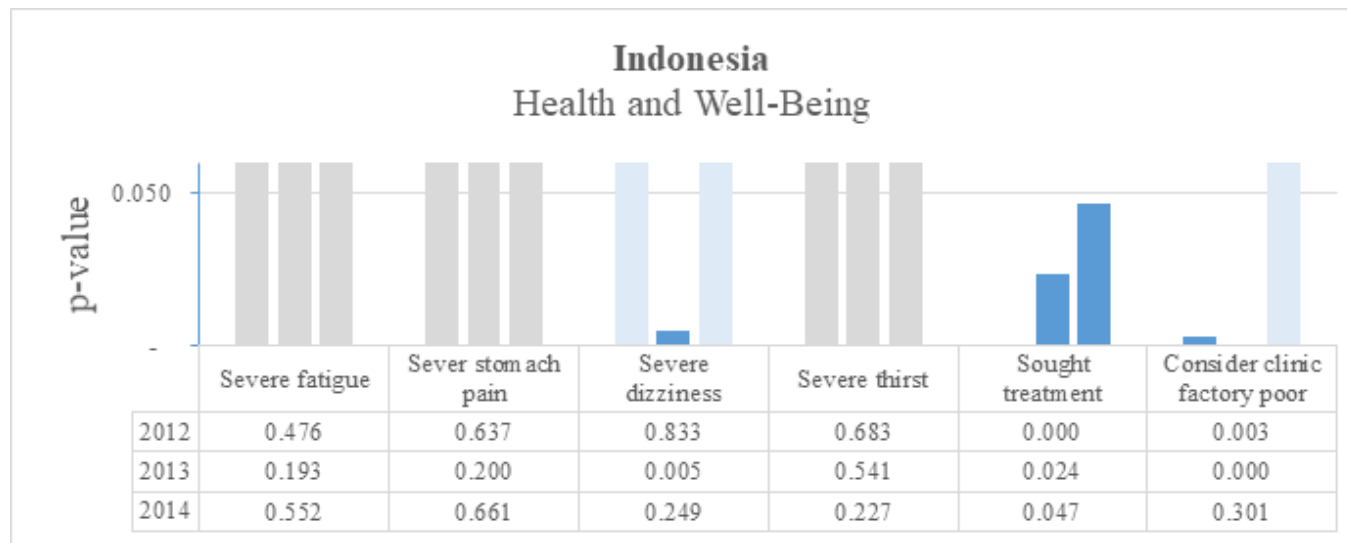

Figure 5. Indonesia: Health and well-being

well-being matters. According to the author's calculation, there seems to be no indicators of health that have significant dissimilarities between the genders. Still, it should be noted that the percentage for workers with severe thirst is quite statistically robust as each gender yields in percentage of more than 60 percent. There seems to be little amount of complain about the quality of factory clinic.

\section{Perceived Barriers and Voice}

From Figure 6, physical abuse seems to be an issue which the male workers significantly more concerned about than the female workers. However, in general, the workers in Indonesian garment factories seem to perceive their working environment to be fair and comfortable as the statistics show majority of the workers agreed to positive indicators in creating the working environment. The involvement of Better Work program may have positively influence the more apparent compliance matters such as the supervisor-worker relationship.

\section{Understanding Gender Inequality in the Workplace}

While there is little evidence on significant difference in health and well-being and perceived barriers between female workers and male workers, garment factories under Better Work program in Indonesia are persistence on the acts of other dimensions of gender inequality- 


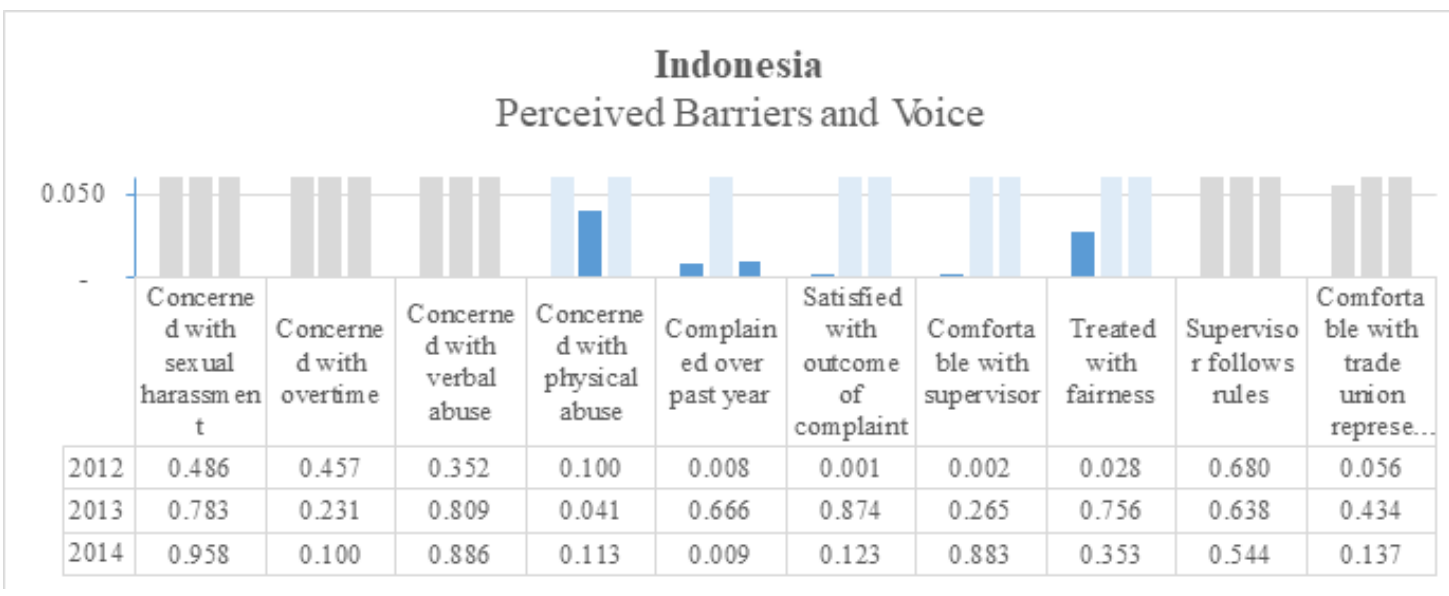

Figure 6. Indonesia: Perceived barriers and voice

which even more prominent in the dimensions of occupational distribution, wage gap, and training and promotion. Hence, a further research in understanding gender inequality for each country is necessary.

In Indonesia, there are several reasons why gender inequality is still occurred. First, the strong role of patriarchy in the society seems to be one of the most prominent issue in Indonesia. Based on the evidence of women sociocultural status in Indonesia, it can be suggested that the society is still highly gendered and that the concept of patriarchy has a prominent role in dictating the role of women (Kercheval, et al., 2013). In Indonesia, the gender divisions are infused into the modern Indonesia society as women typically presume a domestic role to raise the children and support the husband, whereas as the husband, men are expected to be visible in public sphere (Dzuhayatin, 2003). The concept of female domestication is based on the idea of "ibuism" - a state's mindset regarding gender dorms which highlights the domesticity of Indonesian women and dependency on their husbands (Indraswari, 2006). Empirical findings suggest that Indonesian government also play a prominent role in implementing such view in the society. According to Dzuhayatin, the Indonesian "...state encourages women to meet the ideal type that is portrayed as a married woman, preferably a housewife or possibly a medium career and under no circumstances can be higher than her husband" (Dzuhayatin, 2003). In addition, the 1989 State Guidelines that are still used today explains the state's perception of the ideal Indonesian women: "loyal supporter of the husband; producer and educator of future generations; caretaker of the household; additional economic provider for the family; members of Society" (Dzuhayatin, 2003). This sort of view endorses that a woman will always have a dual role - to work and earn money for the economy, but also to serve her husband and family in the household (La Botz, 2001).

Second, Gender stereotype which is due to the patriarchy concept implemented in the Indonesian society ascribe men with the breadwinner status. The concept is deeply rooted that more than often, it translates to the context of workplace-which as a result, dictate many of the decisions made within the working environment to be in accordance with the view of men as the dominant gender (Eagly \& Sczesny, 2009). A workplace that highly impose men's point of view may be unlikely to have gender-friendly environment and policies, especially those which concern the necessity of female employees. In addition, working women in Indonesia may be looked 
down upon as this is commonly taken as hint that the husband failed to provide for the family (Goldin, 1994). Consequently, the work performance of women can be undermined under the pressure of being judged due to the negative views associated with working women. From this, it can also be argued that the decrease of performance may perpetuate the stereotype of Indonesian women being less productive even further.

Lastly, as the largest population of Muslim in the world, Islam has understandably become an important aspect of the nation's identity. As the largest population of Muslim in the world, Islam has understandably become an important aspect of the nation's identity. The Islam in Indonesia is characterized by a diverse set of beliefs and represents a heterogeneous blend of customs and practices with general classification as moderate and liberal, thus the Muslim women in Indonesia are granted higher social position in comparison to the Muslim women in other part of the world (Wanandi, 2002). Regardless of the "better" treatment, the complexity of Islam and their interpretations in the Indonesian context may serve as a barrier to female's participation in the formal labor market.

The religious texts of Islam such as Quran and Hadith have wide range of interpretations in mind, thus it is difficult to claim that the texts present a universal statement about the differences in roles attributed to men and women. However, the texts can indeed be interpreted conservatively in a manner that places women in a position subordinate to men. So, it can be argued that Islam is in a way also tied to the patriarchal norms mentioned in the earlier part. The combination of gender stereotype and publicly-accepted Islam-promoted patriarchy can make it problematic for Indonesian women to participate the formal labor market comfortably. While the judiciary system in Indonesia is not based on Sharia law-a set of laws within Islam derived from materials in Quran and Hadith, the state has historically shown its willingness to help Muslim practice their religion. Thus, several Sharia law that could adversely impact women and their independency (e.g. inheritance law that states a son should inherit twice as much as a daughter) may still be bounded in the society.

\section{Discussions}

Several factors of gender inequality were still persisting among the factories in Indonesia. Occupational segregation is apparent in the garment factories. most of the findings in the division of work are consistent with the study done by Anker (1997) regarding the common women stereotypes and the way they affected what would be described as "females job" and "males job", the average highest level of education for workers in Indonesia is junior high/ lower secondary school and the male workers in both countries significantly attain higher level of education. But the workers in Indonesia report high percentage of comfort in voicing their voice, whether through supervisor and/or trade union representative. In understanding gender inequality, it is found that the concept of patriarchy is robust in Indonesia and very much rooted in their society through many domains, such as regulations, gender stereotype, and religion. 


\section{References}

ASEAN Secretariat. (2008). ASEAN Economic Community Blueprint. Jakarta: ASEAN Secretariat.

Better Work. (2013). Analysing Better Work Data from a Gender Perspective: A Prelimenary Expoloration of Worker Surveys with Focus on Vietnam. Geneva: International Labour Office.

Braddock, J. (2011). Nike faces allegations of worker abuse in Indonesia. Retrieved March 13, 2016, from https://www.wsws.org/en/articles/2011/09/nike-s08.html

Brown, D., Dehejia, R., Jacobs, F., Mukand, S., Rappaport, A., Robertson, R., Rosenthal, T. (2011, October 5). Measuring the Impact of Better Work. Retrieved May 28, 2016, from http://betterwork.org/global/wp-content/uploads/Session-4-Measuring-the- impact-ofBetter-Work.pdf

Chu, K., \& Davis, B. (2015). As China's Workforce Dwindles, the World Scrambles for Alternatives. Retrieved March 12, 2016, from http://www.wsj.com/articles/as-chinasworkforce-dwindles-the-world-scrambles-for-alternatives-1448293942

Dzuhayatin, S. R. (2003). Islam, patriarchy and the state in Indonesia. Retrieved 2016, from http://www.law.emory.edu/ihr/worddocs/ruhainil.doc

Eagly, A. H., \& Sczesny, S. (2009). Stereotypes about women, men, and leaders: Have times changed? In M. Barreto, M. K. Ryan, \& M. T. Schmitt (Eds.), The glass ceiling in the 21st century: Understanding barriers to gender equality (pp. 21-47). Washington, DC: American Psychological Association.

Fingar, C. (2015). China's dominance of manufacturing FDI on the wane. Retrieved 2016, from https://next.ft.com/content/d87e9b80-2490-11e5-9c4e-a775d2b173ca

Ghosh, P. (2014). Despite Low Pay, Poor Work Conditions, Garment Factories Empowering Millions Of Bangladeshi Women. Retrieved March 19, 2016, from http://www.ibtimes. com/despite-low-pay-poor-work-conditions-garment-factories-empowering-millionsbangladeshi-women-1563419

Goldin, C. (1994). The U-shaped female labor function in economic development and economic history. National Bureau of Economic Research Working Paper Series.

ILO. (2014). Wages and working hours in the textiles, clothing, leather and footwear industries. Geneva: International Labour Organization.

ILO. (2015). Asia-Pacific Garment and Footwear Sector Research Note. Bangkok: ILO Regional Office for Asia and the Pacific. 
Indraswari. (2006). Women and warung in urban kampung. Australian National University. Jiaxing, \& Yangon. (2015). A tightening grip. Retrieved March 12, 2016, from http://www. economist.com/news/briefing/21646180-rising-chinese-wages-will-onlystrengthen- asias-hold-manufacturing-tightening-grip

Kavoussi, B. (2013). Nike Factory In Indonesia Used Military To Intimidate Workers Into Giving Up Pay: Report. Retrieved March 13, 2016, from http://www.huffingtonpost. com/2013/01/15/nike-indonesia_n_2481236.html

Kercheval, J., Markowitz, D., Monson, K., \& Read, B. (2013). Research on Barriers to Employment and Decent Work for Women. ILO.

La Botz, D. (2001). Made in Indonesia: Indonesian workers since Suharto. Cambridge, MA: South End Press.

McKinsey. (2014). Southeast Asia at the Crossroads: Three Paths to Prosperity. Singapore: McKinsey Global Institute.

Rees, D. (2014). Improving conditions for women workers has a domino effect. Retrieved March 17, 2016, from http://www.theguardian.com/sustainable-business/womengarmet-workers-conditions

Straits Times. (2015). Straits Times. Retrieved March 12, 2016, from http://www.straitstimes. com/business/6-things-you-need-to-know-about-asean-economic-community

Wanandi, J. (2002). Islam in Indonesia: Its history, development and future challenges. AsiaPacific Review, 9(2), 104-12.

World Bank. (2013). Gender at Work. Retrieved May 8, 2016, from http://www.worldbank. org/content/dam/Worldbank/document/Gender/GenderAtWork_web.pdf

World Bank Group. (2011). World Bank eAtlas of gender. Retrieved 12 15, 2015, from http:// www.app.collinsindicate.com/worldbankatlas-gender/en-us

WTO. (2015). International Trade Statistics 2015. Retrieved May 19, 2016, from https://www.wto.org/english/res_e/statis_e/its2015_e/its2015_e.pdf 